\title{
Evaluation of Regular Multistory Buildings Using IBC2009 Code and ESEE Regulations by Pushover Analysis Method
}

\author{
Mohamed Sobaih', Ahmed Mousa² \\ ${ }^{1}$ Department of Structural Engineering, Cairo University, Gize, Egypt \\ ${ }^{2}$ Frederick University, Nicosia, Cyprus \\ Email: msobaih2@yahoo.com, a.mmmousa@live.com
}

How to cite this paper: Sobaih, M. and Mousa, A. (2016) Evaluation of Regular Multistory Buildings Using IBC2009 Code and ESEE Regulations by Pushover Analysis Method. Open Journal of Civil Engineering, 6, 595-617.

http://dx.doi.org/10.4236/ojce.2016.64049

Received: June 4, 2016

Accepted: September 12, 2016

Published: September 16, 2016

Copyright $\odot 2016$ by authors and Scientific Research Publishing Inc. This work is licensed under the Creative Commons Attribution International License (CC BY 4.0).

http://creativecommons.org/licenses/by/4.0/

\section{Abstract}

For structural design and assessment of reinforced concrete members, the nonlinear analysis has become an important tool. The purpose of the pushover analysis is to assess the structural performance by estimating the strength and deformation capacities using static, nonlinear analysis and comparing these capacities with the demands at the corresponding performance levels. This paper aims to compare the results given by IBC2009 code and ESEE regulations. In this paper, four RC frames having 5 , 15, 20 and 30 storeys were designed for seismicity according to both the recently adopted seismic code in Abu Dhabi (IBC2009) and the ESEE regulations. A pushover analysis is carried out for these buildings using SAP2000 (Ver. 15) and the ultimate capacities of the buildings are established. The obtained pushover curves and plastic hinges distributions are used to compare between the IBC2009 code and ESEE regulations. The comparison showed that there was variation in the obtained results by the two codes and the buildings designed by IBC2009 code were more vulnerable.

\section{Keywords}

Pushover Analysis, Seismic Evaluation, ESEE Regulations, IBC2009 Code, Abu Dhabi

\section{Introduction}

Recently, the nonlinear static analysis (NSA) method has emerged as an attractive method for evaluating the performance of new and existing buildings. This is primarily because of the ability of the NSA method to provide estimates of the expected inelastic deformation demands and to help identify design flaws that would be otherwise ob- 
scured in a linear analysis of the building. In addition, the features of the NSA method are available to the structural engineer without the modeling and computational effort of a nonlinear time-history analysis. Therefore, extensive research efforts have been devoted to investigatingthe structural behavior under seismic loads by using pushover analysis.

Sung et al. (2013) [1] investigated the shear failure behavior of beam-column joints (BCJs) of RC frame structures by the means of nonlinear static pushover analysis (NSPA). The authors proposed a new NSPA procedure to assess effectively the shear failure of BCJs and its seismic capacity and the progressive failure of the joints. Furthermore, they provided novel plastic hinges (PHS) characteristics of BCJs and an innovative cross-strut model to simulate detailed joint behavior in NSPA. The analytically derived pushover curves were compared to three different full-scaled RC frames to validate the proposed methodology.

Hassaballa et al. (2014) [2] performed a 3D NSPA to study the performance of existing four-storey RC flat slab building in both positive and negative $\mathrm{X}$ and $\mathrm{Y}$ directions separately. The evaluation was carried out by using SAP2000 software (Ver. 14) [3]. It was observed from the analysis that the building was not safe and needed retrofitting in the X-direction because there were some elements exceeded the limit level between life safety (LS) and collapse prevention (CP), whereas, all structural elements did not reach the limit in Y-direction.

Maske et al. (2014) [4] performed 3D NSPA on 5 and 15 storeys frame structures using SAP2000 software (Ver. 14). A detailed description of pushover method and capacity curve properties was presented. In addition, the authors evaluated different parameters that affected seismic assessment of frame structures, e.g. pushover and capacity curves. It was concluded that the considered case studies performed reasonably under seismic loads.

Choudhary and Wadia (2014) [5] investigated the effect of shear walls on the seismic performance of the RC frame structures. Two case studies were considered in the analysis, in which one was symmetrical building and the other was unsymmetrical building (i.e. L-shaped building). It was found that providing shear walls led to a significant decrease in both buildings. Moreover, placing the shear walls in the short direction is mandatory for the unsymmetrical building since they provide more reduction in roof displacement.

Aleksieva (2015) [6] conducted a comparative study between the NSPA and incremental dynamic analysis (IDA) to investigate the structural behavior of a RC threestorey frame building under the seismic loading. The aim of the paper was to highlight the advantages of each method and their applicability in structural seismic design. The OpenSees software [7] was used to conduct the analysis of the building. It was concluded that the pushover analysis produced accurate results in the elastic region, whereas the results were very conservative in the nonlinear region.

Kadlag and Kenkar (2016) [8] performed a parametric study to investigate the impact of the variation of bay width and base condition on the structural behavior of RC 
frames by the means of pushover analysis. To investigate the soil-structure interaction (SSI) effects, three base conditions were considered which were fixed base, medium soil and soft soil. Moreover, the RC framed buildings' height was $G+10, G+15$ and G +20 and the width varied from 4 to 5 meters. It was observed that with the increase of bay width and building height, the number of failed PHs was increasing as well for all the base conditions.

Keerthan and Babu (2016) [9] carried out a pushover analysis on 3D 10 storeys RC frames in order to investigate the effect of mass irregularities on the structural behavior under severe earthquakes. ETABS software (Ver. 9.7) was used to carry out the pushover analysis. The main findings of study were that the increase in lateral displacement of mass irregular frame was promotional to the heavy mass floor level. Furthermore, the mass irregular RC frames experienced significant interstorey drifts compared to the regular RC frames.

The focus of this paper is on the evaluation of the nonlinear performance of regular multi-storey reinforced concrete buildings using the NSA and pushover analysis under the loads of the IBC2009 [10] and the Regulations of the Egyptian Society for Earthquake Engineering (ESEE) [11]. Moreover, the obtained pushover curves and plastic hinges distributions are used to compare between the IBC2009 code and ESEE regulations. The outcome of this study is to check the vulnerability of both codes, and to provide useful information for further seismic designs in UAE.

\section{Pushover Analysis}

Pushover analysis is a static nonlinear procedure in which the magnitude of the lateral force is incrementally increased, maintaining the predefined distribution pattern along the height of the building. With the increase in the magnitude of the loads, weak links and failure modes of the building are found [12]. Pushover analysis can determine the behavior of a building, including the ultimate load and the maximum inelastic deflection. Local nonlinear effects are modeled and the structure is pushed until a collapse mechanism gets developed. At each step, the base shear and the roof displacement can be plotted to generate the pushover curve. It gives an idea of the maximum base shear that the structure was capable of resisting at the time of the earthquake. For regular buildings, it can also give an estimate about the global stiffness of the building [13].

In this paper, the lateral loads were applied monotonically in a step-by-step nonlinear static analysis. The applied lateral loads were accelerations in the $\mathrm{x}$ direction representing the forces that would be experienced by the structures when subjected to ground shaking. Under incrementally increasing loads some elements may yield sequentially. Consequently, at each event, the structures experiences a stiffness change as shown in Figure 1, where IO, LS and CP stand for immediate occupancy, life safety and collapse prevention, respectively.

\section{Earthquake Loads}

The seismic loads applied on the frame building are calculated according to the rules 


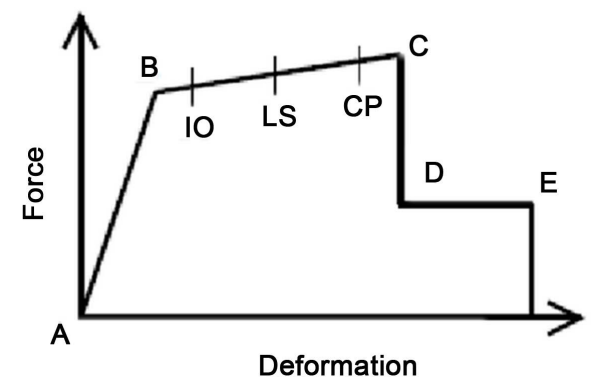

Figure 1. Force-deformation for pushover hinge [14].

which are given in the International Building Code IBC2009 and the Regulations for earthquake-Resistant Design of Buildings in Egypt (ESEE). The loads obtained by IBC2009 are calculated directly by the SAP2000 software, whereas, the seismic loads from ESEE regulations are calculated manually.

\subsection{Seismic Loads According to IBC2009 Code}

IBC2009 requires that all structural element design resist earthquake motions in accordance with ASCE 7-05 [15]. The SAP2000 allows users to activate Special seismic load effects using appropriate commands on the Define menu. The special seismic loads are computed in accordance with ASCE 7-05 sections 12.3.4 and 12.4. By default, the program computes the reliability factor in accordance with IBC2009, unless overwritten by the user. The reliability factor, $\rho$, and dead load (DL) multiplier are automatically applied to all program default design combinations when the ACI 318-08/ IBC2009 [16] code is selected.

The DL multiplier represents the $0.2 \mathrm{~S}_{\mathrm{DS}}$ factor in Equation 12.4-4 of ASCE 7-05. The program default value is 0.2 . When seismic load $\mathrm{E}$ is combined with the effects of other loads, the following load combinations shall be used in lieu of the seismic load combinations in section 9.2.1 of ACI 318-08 [16].

$$
\begin{gathered}
\left(0.9-0.2 S_{D S}\right) D \pm \rho E \\
\left(1.2+0.2 S_{D S}\right) D+1.0 L \pm \rho E \\
\left(1.2+0.2 S_{D S}\right) D+1.0 L+0.2 S \pm \rho E
\end{gathered}
$$

where:

D: Dead load.

$L$ : Live load.

$E$ : Earthquake load.

$S$ : Snow load.

$\rho$ : The reliability factor.

$S_{D S}$ : Design spectral response acceleration parameter at short periods obtained from ASCE 7-05, Section 11.4.4.

\subsection{Seismic Loads According to ESEE Regulations}

The Egyptian Society for Earthquake Engineering has published its "Regulations for 
earthquake-Resistant Design of Buildings in Egypt". These regulations have been proven to be more adequate for seismic safety of buildings in Egypt. It was recommended that these regulations be compared with international codes. Therefore, it has been chosen in this paper to compare these Regulations by the results obtained by applying the used code in Abu Dhabi.

Using the static lateral force procedure and according to the Regulations of the Egyptian Society for Earthquake Engineering (ESEE 1988) [12] every building shall be designed and constructed to withstand a total horizontal seismic force $(V)$ and estimated as explained in section 3.11.1 and clause 2.3.2.1 of the ESEE Regulations. According to ESEE, the total seismic base shear force $V$ is determined as follows:

$$
V=C_{s} W_{t}
$$

where:

$V$ is the total horizontal seismic force at the base, $C_{s}$ is the seismic coefficient determined as follows:

$$
C_{s}=Z I S M R Q \leq(4.8 Z I M Q)
$$

where:

$Z$ is the seismic zoning factor and shall be determined according to the equation (3.17) as follows:

$$
Z=A C F
$$

where:

$A$ is a standard value for horizontal acceleration ratio.

$C$ is the coefficient of the standardized response spectrum for average damping of $5 \%$.

$F$ is the foundation soil factor.

$I$ is the importance factor.

$S$ is the Structural system type factor.

$M$ is the material factor.

$R$ is the risk factor.

$Q$ is the construction quality factor.

$W_{t}$ is the total weight, and it is evaluated from:

$$
\begin{gathered}
W_{t}=\sum_{i=1}^{n} W_{i} \\
W_{i}=D_{i}+p L_{i}
\end{gathered}
$$

where $D_{i}$ is the total dead load for the $i$ th floor, $L_{i}$ is the total live load for the $i$ th floor, and $\mathrm{p}$ is the incidence factor for live load as seen in Table 1.

Table 1. Incidence factor for live loads "p".

\begin{tabular}{cc}
\hline Type of Structure & $\mathrm{p}$ \\
\hline Residential buildings, hotels, offices, hospitals, public buildings, etc. & 0.25 \\
Storage areas and warehouses ${ }^{1}$. & 0.5 \\
\hline
\end{tabular}

${ }^{1}$ Tanks, reservoirs, silos and the like shall be considered to contain their full contents. 
The seismic coefficient $C_{S}$ shall not be taken greater than (4.8ZIMQ) and shall-in no case-be taken less than (0.02) in non-zero seismic zones.

\section{Distribution of Horizontal Seismic Forces:}

For a regular building, the total base shear calculated from Equation (4) shall be distributed over the height of the building laterally, the equation of distribution is:

$$
F_{i}=\left(\frac{W_{i} h_{i}}{\sum_{i=1}^{n} W_{i} h_{i}}\right)\left(V-F_{t}\right)
$$

where:

$F_{i}$ is that part of the total horizontal seismic force assigned to the $i$ th floor.

$W_{i}$ is the total load on the $i$ th floor.

$h_{i}$ is the height over the base to the level of the ith floor.

$V$ is the total base shear.

$F_{t}$ is additional concentrated force at top storey and shall be determined as follows:

$F_{t}=0.0$ for $H / d<3.0 \mathrm{~m}$;

$F_{t}=0.1 \mathrm{~V}$ for $H / d>3.0 \mathrm{~m}$;

$F_{t}=0.2 \mathrm{~V}$ for chimneys and smoke-stacks resting on the ground;

where $H / d$ is the height to width ratio of the building.

\section{Description of Studied Cases}

In this study, pushover analyses were performed on four concrete frame models which are consisted of two bays. The typical bay width and storey height of the four models are 5.0 and 3.0 meters, respectively. The ground floor height is 5.0 meters to take into account the foundation depth. Since the common soils in UAE are generally classified as weak soils, the buildings are usually founded on piles or raft foundations. This is reflected in the prototype buildings by choosing the support condition of the columns to be fixed. The four models neglect the effects of torsion in buildings subjected to earthquakes assuming that the center of mass of the building coincides with the center of rigidity of its columns. The selected numbers of storeys of the RC buildings are 5, 15, 20 and 30 storeys as shown in Figure 2. The models are analyzed and designed under gravity and seismic loads using SAP2000 software (Ver.15) [17]. The following assumptions are considered for lateral elastic analysis:

1. Shear deformation effects are neglected.

2. Non-structural elements and in-fill walls are neglected.

3. Buildings are modeled as 2-D frames with fixed supports at the foundation level.

4. The out-of-plane deformations are absorbed by the rigid horizontal diaphragms.

5. Cracked sections for beams and columns are used in the analysis.

6. The floor diaphragms are rigid enough to distribute uniformly the lateral loads on the vertical elements.

The lateral force resisting system consists of intermediate resisting moment frames without shear walls. The rectangular shape is used for the edge columns, whereas the square shape is used for the central columns. In addition, beams are provided with the reinforcement according to the maximum moment at top and bottom. 


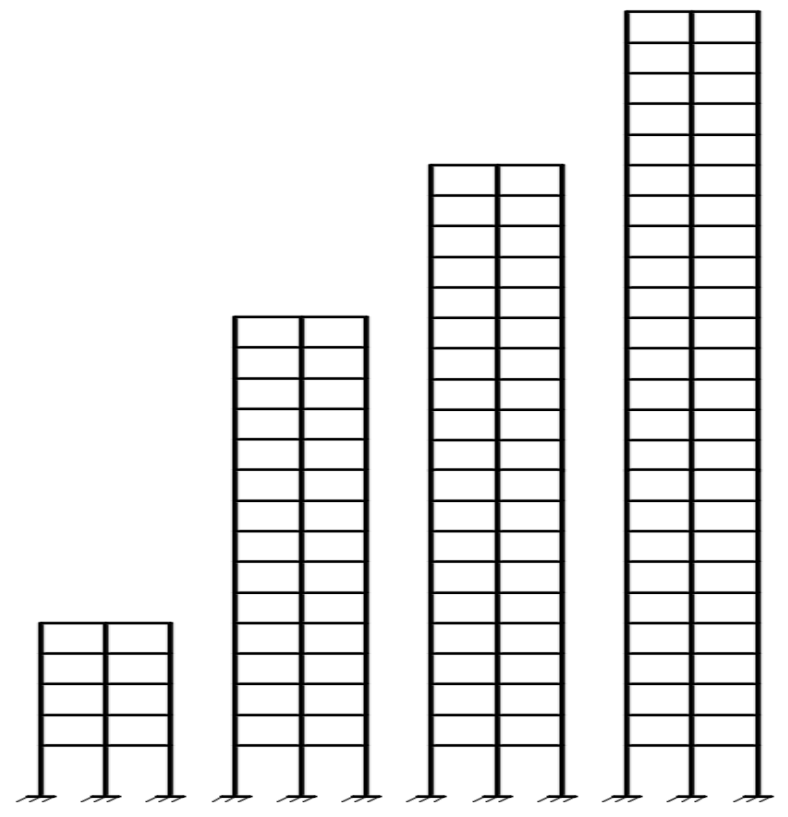

Figure 2. Models of 5, 15, 20 and 30-storey buildings.

\section{Results and Discussion}

This part presents the results of the analysis and design of considered RC buildings. It also provides a through comparison between the IBC2009 code and the ESEE regulations to investigate which code produces buildings that are more vulnerable.

\subsection{Beams Sections Design}

All the beam elements are designed to withstand the maximum bending moments and shear forces applied on them. The section properties for IBC2009 code and ESEE regulations are shown in Table 2; both codes have the same reinforcement for beams.

\subsection{Columns Sections Design}

All the columns elements are designed to withstand the maximum bending moments and axial forces that are applied on them. Tables 3-6 show the designed columns according to IBC2009 code. Similarly, Tables 7-10 shows the designed columns according to ESEE regulations.

\subsection{Comparison of Pushover Curves}

Figures 3-6 show the differences between each building using the IBC2009 code with its identical case using the ESEE regulations.

From the comparison of the 5-storey with its identical case in the ESEE regulations as shown in Figure 3, we can notice that there are obvious differences in values between the two codes. The ESEE regulations gives mush larger base shear, but they are similar to each other in terms of total displacement.

From the comparison of the 15-storey as shown in Figure 4, we found that the base 
Table 2. Beam section properties according to IBC2009 code and ESEE regulations.

\begin{tabular}{ccccc}
\hline Building & Floors & Section Name & Reinforcement Top & Reinforcement Bot \\
\hline 5 Storey & 1 to 4 & B $250 \times 500$ & $5 \Phi 14$ & $5 \Phi 14$ \\
& 5 & B $250 \times 500$ & $5 \Phi 12$ & $5 \Phi 10$ \\
15 Storey & 12 to 15 & B $250 \times 600$ & $4 \Phi 14$ & $4 \Phi 12$ \\
& 7 to 11 & B $250 \times 700$ & $4 \Phi 14$ & $4 \Phi 12$ \\
& 1 to 6 & B $250 \times 800$ & $5 \Phi 14$ & $5 \Phi 12$ \\
20 Storey & 15 to 20 & B $250 \times 600$ & $4 \Phi 14$ & $4 \Phi 12$ \\
& 9 to 14 & B $250 \times 700$ & $4 \Phi 14$ & $4 \Phi 12$ \\
& 1 to 8 & B $250 \times 800$ & $5 \Phi 14$ & $3 \Phi 14$ \\
& 23 to 30 & B $250 \times 600$ & $4 \Phi 14$ & $4 \Phi 12$ \\
30 Storey & 17 to 22 & B $250 \times 700$ & $4 \Phi 14$ & $4 \Phi 12$ \\
& 10 to 16 & B $250 \times 800$ & $5 \Phi 14$ & $4 \Phi 12$ \\
\hline
\end{tabular}

Table 3. Column section properties for 5 storey building according to IBC2009 code.

\begin{tabular}{cccccc}
\hline Section Name & $\begin{array}{c}\text { No. of Bars in } \\
\text { 3-Dir. }\end{array}$ & $\begin{array}{c}\text { No. of Bars in } \\
\text { 2-Dir. }\end{array}$ & $\begin{array}{c}\text { Main } \\
\text { Reinforcement }\end{array}$ & $\begin{array}{c}\text { No. } \\
\text { of Stirrups }\end{array}$ & $\begin{array}{c}\text { Spacing of Stirrups } \\
\text { and (diameter) } \\
\text { m (mm) }\end{array}$ \\
\hline EC $600 \times 300$ & 4 & 4 & $12 \Phi 14$ & & \\
EC $700 \times 400$ & 3 & 6 & $14 \Phi 16$ & 4 & $0.15(10)$ \\
IC $600 \times 600$ & 3 & 3 & $8 \Phi 20$ & & \\
\hline
\end{tabular}

Table 4. Column section properties for 15 storey building according to IBC2009code.

\begin{tabular}{|c|c|c|c|c|c|}
\hline Section Name & $\begin{array}{l}\text { No. of } \\
\text { Bars in } \\
\text { 3-Dir. }\end{array}$ & $\begin{array}{l}\text { No. of } \\
\text { Bars in } \\
\text { 2-Dir. }\end{array}$ & $\begin{array}{c}\text { Main } \\
\text { Reinforcement }\end{array}$ & $\begin{array}{l}\text { No. } \\
\text { of Stirrups }\end{array}$ & $\begin{array}{c}\text { Spacing of Stirrups } \\
\text { and (diameter) } \\
\text { m (mm) }\end{array}$ \\
\hline EC $300 \times 1000$ & 2 & 5 & $10 \Phi 20$ & \multirow{10}{*}{4} & \multirow{10}{*}{$0.15(10)$} \\
\hline EC $300 \times 1100$ & 3 & 4 & $12 \Phi 20$ & & \\
\hline EC $300 \times 700$ & 2 & 4 & 8 Ф 20 & & \\
\hline EC $300 \times 800$ & 2 & 4 & $8 \Phi 20$ & & \\
\hline EC $300 \times 900$ & 2 & 5 & $10 \Phi 20$ & & \\
\hline IC $500 \times 500$ & 3 & 3 & $8 \Phi 25$ & & \\
\hline IC $600 \times 600$ & 3 & 3 & $8 \Phi 25$ & & \\
\hline IC $700 \times 700$ & 3 & 4 & $10 \Phi 25$ & & \\
\hline IC $800 \times 800$ & 4 & 5 & $14 \Phi 25$ & & \\
\hline IC $900 \times 900$ & 4 & 5 & 14 Ф 28 & & \\
\hline
\end{tabular}


Table 5. Column section properties for 20 storey building according to IBC2009code.

\begin{tabular}{|c|c|c|c|c|c|}
\hline Section Name & $\begin{array}{l}\text { No. of } \\
\text { Bars in } \\
\text { 3-Dir. }\end{array}$ & $\begin{array}{l}\text { No. of } \\
\text { Bars in } \\
\text { 2-Dir. }\end{array}$ & $\begin{array}{c}\text { Main } \\
\text { Reinforcement }\end{array}$ & $\begin{array}{c}\text { No. } \\
\text { of Stirrups }\end{array}$ & $\begin{array}{c}\text { Spacing of Stirrups } \\
\text { and (diameter) } \\
\text { m (mm) }\end{array}$ \\
\hline EC $300 \times 1100$ & 2 & 6 & 12 Ф 20 & \multirow{10}{*}{4} & \multirow{10}{*}{$0.15(10)$} \\
\hline EC $300 \times 1200$ & 2 & 6 & $12 \Phi 20$ & & \\
\hline EC $300 \times 700$ & 2 & 4 & $8 \Phi 20$ & & \\
\hline EC $300 \times 900$ & 2 & 5 & $10 \Phi 20$ & & \\
\hline EC $400 \times 1300$ & 2 & 6 & $12 \Phi 25$ & & \\
\hline IC $1000 \times 1000$ & 6 & 6 & 20 Ф 26 & & \\
\hline IC $600 \times 600$ & 3 & 3 & $8 \Phi 25$ & & \\
\hline IC $700 \times 700$ & 3 & 4 & $10 \Phi 25$ & & \\
\hline IC $800 \times 800$ & 4 & 5 & $14 \Phi 25$ & & \\
\hline IC $900 \times 900$ & 5 & 5 & $16 \Phi 26$ & & \\
\hline
\end{tabular}

Table 6. Column section properties for 30 storey building according to IBC2009code.

\begin{tabular}{|c|c|c|c|c|c|}
\hline Section Name & $\begin{array}{l}\text { No. of Bars in } \\
\text { 3-Dir. }\end{array}$ & $\begin{array}{l}\text { No. of Bars in } \\
\text { 2-Dir. }\end{array}$ & $\begin{array}{c}\text { Main } \\
\text { Reinforcement }\end{array}$ & $\begin{array}{c}\text { No. } \\
\text { of Stirrups }\end{array}$ & $\begin{array}{c}\text { Spacing of Stirrups } \\
\text { and (diameter) } \\
\text { m (mm) }\end{array}$ \\
\hline EC $300 \times 1100$ & 2 & 6 & 12 Ф 20 & & \\
\hline EC $300 \times 1200$ & 2 & 6 & $12 \Phi 20$ & & \\
\hline EC $300 \times 1300$ & 2 & 7 & 14 Ф 20 & & \\
\hline EC $300 \times 700$ & 2 & 4 & $8 \Phi 20$ & & \\
\hline EC $300 \times 900$ & 2 & 5 & 10 Ф 20 & 4 & $0.15(10)$ \\
\hline EC $400 \times 1400$ & 2 & 7 & $14 \Phi 25$ & & \\
\hline EC $400 \times 1500$ & 2 & 7 & 14 Ф 25 & & \\
\hline IC $1000 \times 1000$ & 6 & 6 & $20 \Phi 26$ & & \\
\hline IC $1100 \times 1100$ & 6 & 6 & 20 Ф 28 & & \\
\hline IC $500 \times 500$ & 3 & 3 & $8 \Phi 25$ & & \\
\hline
\end{tabular}

Table 7. Column section properties for 5 storey building according to ESEE regulations.

\begin{tabular}{cccccc}
\hline Section Name & $\begin{array}{c}\text { No. of } \\
\text { Bars in } \\
\text { 3-Dir. }\end{array}$ & $\begin{array}{c}\text { No. of } \\
\text { Bars in } \\
\text { 2-Dir. }\end{array}$ & $\begin{array}{c}\text { Main } \\
\text { Reinforcement }\end{array}$ & $\begin{array}{c}\text { No. of } \\
\text { Stirrups }\end{array}$ & $\begin{array}{c}\text { Spacing of Stirrups } \\
\text { and (diameter) } \\
\text { m (mm) }\end{array}$ \\
\hline EC $600 \times 300$ & 4 & 4 & $12 \Phi 14$ & & \\
EC $700 \times 400$ & 3 & 6 & $14 \Phi 16$ & 4 & $0.15(10)$ \\
IC $500 \times 500$ & 3 & 4 & $9 \Phi 20$ & & \\
\hline
\end{tabular}


Table 8. Column section properties for 15 storey building according to ESEE regulations.

\begin{tabular}{cccccc}
\hline Section Name & $\begin{array}{c}\text { No. of } \\
\text { Bars in } \\
\text { 3-Dir. }\end{array}$ & $\begin{array}{c}\text { No. of } \\
\text { Bars in } \\
\text { 2-Dir. }\end{array}$ & $\begin{array}{c}\text { Main } \\
\text { Reinforcement }\end{array}$ & $\begin{array}{c}\text { No. of } \\
\text { Stirrups }\end{array}$ & $\begin{array}{c}\text { Spacing of Stirrups } \\
\text { and (diameter) } \\
\mathrm{m}(\mathrm{mm})\end{array}$ \\
\hline EC $300 \times 1000$ & 2 & 5 & $10 \Phi 20$ & & \\
EC $300 \times 1100$ & 3 & 4 & $12 \Phi 20$ & \\
EC $300 \times 700$ & 2 & 4 & $8 \Phi 20$ & \\
EC $300 \times 800$ & 2 & 4 & $8 \Phi 20$ & \\
EC $300 \times 900$ & 2 & 5 & $10 \Phi 20$ & \\
IC $500 \times 500$ & 3 & 4 & $9 \Phi 25$ & \\
IC $600 \times 600$ & 3 & 4 & $9 \Phi 25$ & \\
IC $700 \times 700$ & 4 & 4 & $11 \Phi 25$ & & \\
IC $800 \times 800$ & 5 & 5 & $15 \Phi 25$ & & \\
IC $900 \times 900$ & 5 & 5 & $15 \Phi 28$ & & \\
\hline
\end{tabular}

Table 9. Column section properties for 20 storey building according to ESEE regulations.

\begin{tabular}{cccccc}
\hline Section Name & $\begin{array}{c}\text { No. of } \\
\text { Bars in } \\
\text { 3-Dir. }\end{array}$ & $\begin{array}{c}\text { No. of } \\
\text { Bars in } \\
\text { 2-Dir. }\end{array}$ & $\begin{array}{c}\text { Main } \\
\text { Reinforcement }\end{array}$ & $\begin{array}{c}\text { No. of } \\
\text { Stirrups }\end{array}$ & $\begin{array}{c}\text { Spacing of Stirrups } \\
\text { and (diameter) } \\
\text { m (mm) }\end{array}$ \\
\hline EC $300 \times 1100$ & 2 & 6 & $12 \Phi 20$ & & \\
EC $300 \times 1200$ & 2 & 6 & $12 \Phi 20$ & \\
EC $300 \times 700$ & 2 & 4 & $8 \Phi 20$ & \\
EC $300 \times 900$ & 2 & 5 & $10 \Phi 20$ & \\
EC $400 \times 1300$ & 2 & 6 & $12 \Phi 25$ & \\
IC $1100 \times 1100$ & 6 & 7 & $21 \Phi 26$ & 4 \\
IC $700 \times 700$ & 3 & 4 & $9 \Phi 25$ & \\
IC $800 \times 800$ & 4 & 4 & $11 \Phi 25$ & \\
IC $900 \times 900$ & 5 & 5 & $15 \Phi 25$ & & \\
IC $1000 \times 1000$ & 5 & 6 & $17 \Phi 26$ & & \\
\hline
\end{tabular}

Table 10. Column section properties for 30 storey building according to ESEE regulations.

\begin{tabular}{cccccc}
\hline Section Name & $\begin{array}{c}\text { No. of } \\
\text { Bars in } \\
\text { 3-Dir. }\end{array}$ & $\begin{array}{c}\text { No. of } \\
\text { Bars in } \\
\text { 2-Dir. }\end{array}$ & $\begin{array}{c}\text { Main } \\
\text { Reinforcement }\end{array}$ & $\begin{array}{c}\text { No. of } \\
\text { Stirrups }\end{array}$ & $\begin{array}{c}\text { Spacing of Stirrups } \\
\text { and (diameter) } \\
\text { m (mm) }\end{array}$ \\
\hline EC $300 \times 1100$ & 2 & 6 & $12 \Phi 20$ & \\
EC $300 \times 1200$ & 2 & 6 & $12 \Phi 20$ & \\
EC $300 \times 1300$ & 2 & 7 & $14 \Phi 20$ & \\
EC $300 \times 700$ & 2 & 4 & $8 \Phi 20$ & \\
EC $300 \times 900$ & 2 & 5 & $10 \Phi 20$ & \\
EC $400 \times 1400$ & 2 & 7 & $14 \Phi 25$ & \\
EC $400 \times 1500$ & 2 & 7 & $14 \Phi 25$ & \\
IC $1100 \times 1100$ & 6 & 7 & $21 \Phi 26$ & \\
IC $1200 \times 1200$ & 6 & 7 & $21 \Phi 28$ & \\
IC $600 \times 600$ & 3 & 4 & $9 \Phi 25$ & \\
IC $700 \times 700$ & 3 & 4 & $9 \Phi 25$ & \\
IC $800 \times 800$ & 4 & 4 & $11 \Phi 25$ & \\
IC $900 \times 900$ & 5 & 5 & $15 \Phi 25$ & \\
IC $1000 \times 1000$ & 5 & 6 & $17 \Phi 26$ & \\
\hline
\end{tabular}




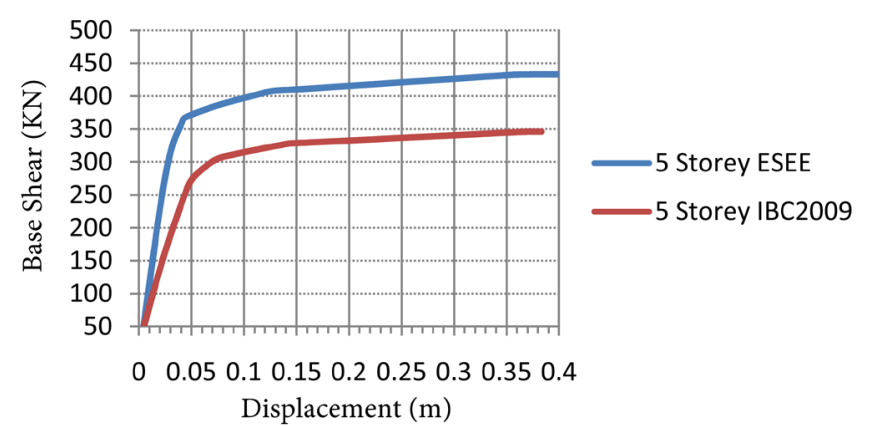

Figure 3. Pushover curves for 5-storey building using IBC2009 and ESEE.

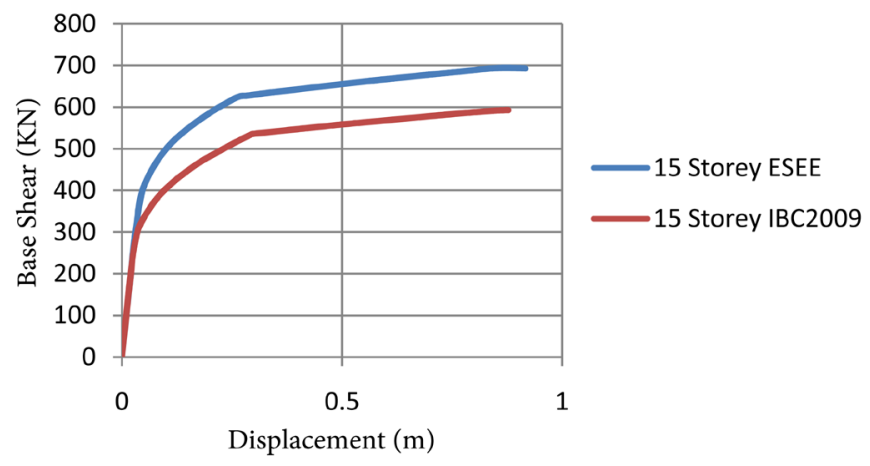

Figure 4. Pushover curves for 15-storey building using IBC2009 and ESEE.

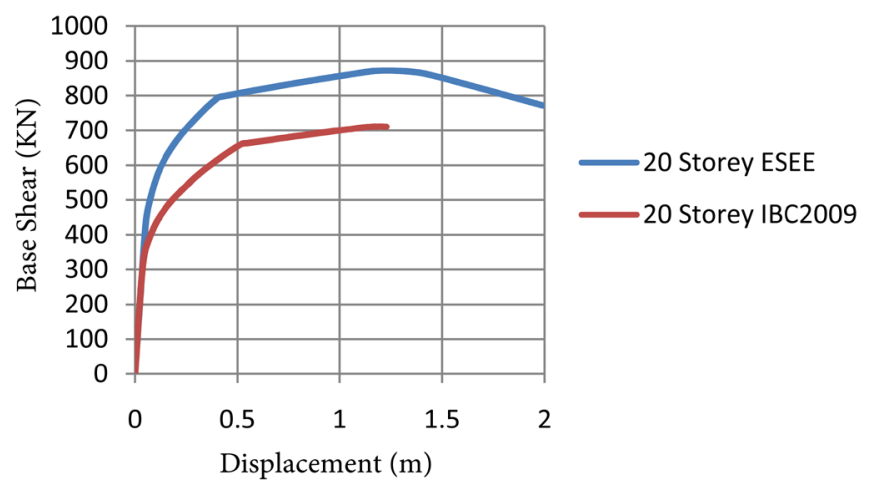

Figure 5. Pushover curves for 20-storey building using IBC2009 and ESEE.

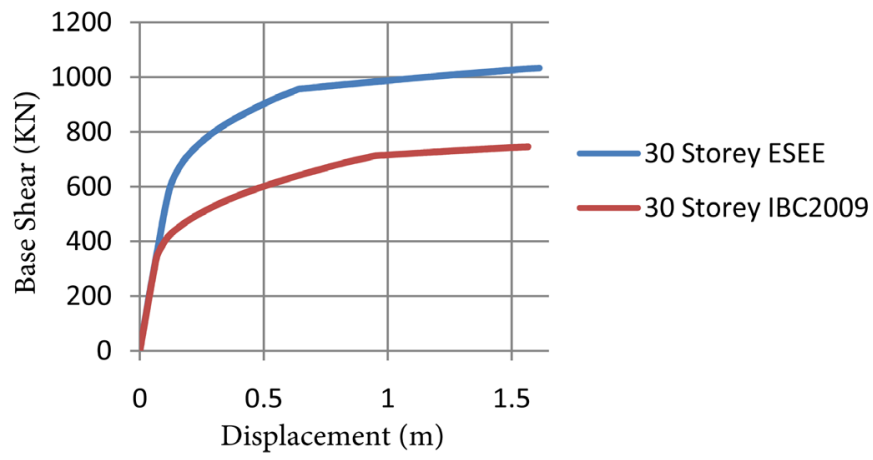

Figure 6. Pushover curves for 30-storey building using IBC2009 and ESEE. 
shear gap between the two models are smaller compared to 5-storey model. Furthermore, the IBC2009 loading code gives lesser total displacement than the ESEE regulation. From Figure 5, we can notice from the comparison of 20-storey model that the ESEE gives higher base shear with much larger total displacement. Moreover, from Figure 6, we found that the comparison of 30-storey model is similar to 5-storey model. It may be concluded that the ESEE-designed buildings were stronger than the IBC2009 buildings, because as the loads increase there is a proportional increase in cross sections and reinforcement.

\subsection{Plastic Hinges Distribution}

Plastic hinges are created at the ends of the beams and at the base of the columns which lead to the foundation. First, the characteristics of plastic hinges have to assign for each section. A crucial force for the beams, a critical for failure, is the moment in the local axis 3 (M3). At the columns, a critical for failure, is the interaction between the axial force $\mathrm{P}$ and the moment in local axes 3 (M3). The characteristics for plastic hinges are given at both ends of the element (relative distance 0 and 1 ).

\subsubsection{Using IBC2009 Loads}

Using the IBC2009 loading code, Figures 7-14 show the plastic hinges distribution caused because of the pushover load affecting the considered RC buildings heights, i.e. 5, 15, 20 and 30 storeys, with fixed load pattern (Uniform load Pattern).

For the 5-storey building, it was found that most of plastic hinges occurred in the beams, which satisfies the weak beam-strong column criteria. Moreover, these plastic hinges were located at the third, fourth and fifth levels with severe damage in beams, as the colors indicate the amount of damage.

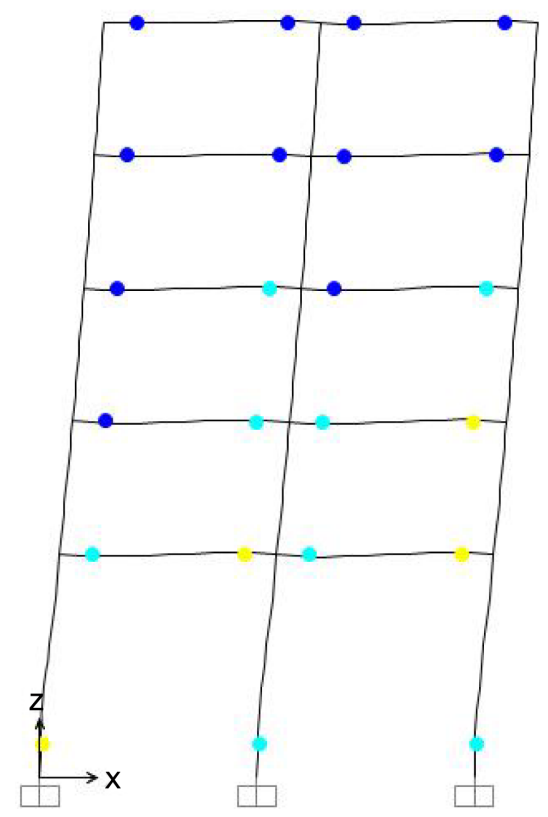

Figure 7. Distribution of hinges in 5-storey building using IBC2009 (CP). 


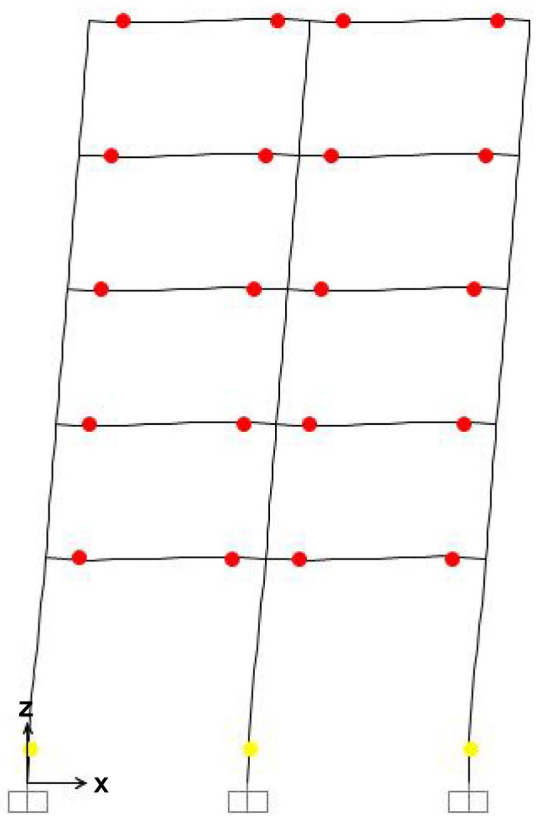

Figure 8. Distribution of hinges in 5-storey building using IBC2009 (E).

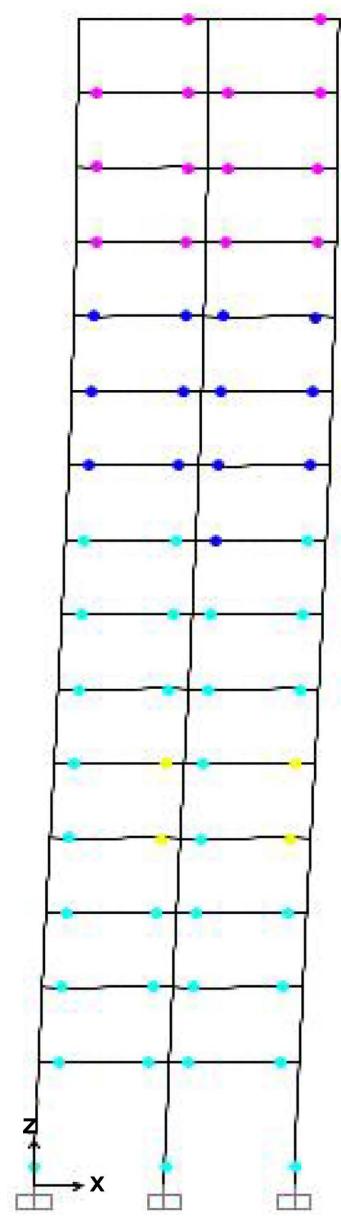

Figure 9. Distribution of hinges in 15-storey building using IBC2009 (CP). 


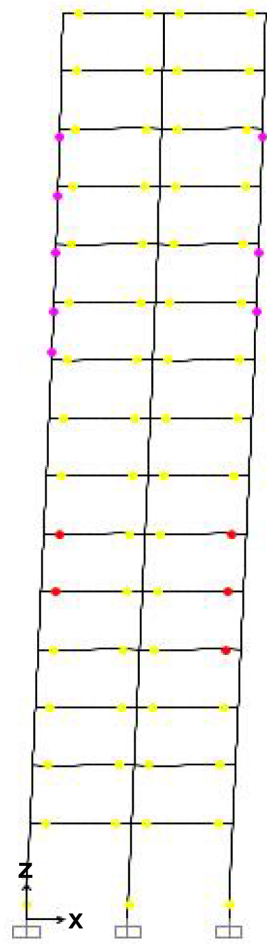

Figure 10. Distribution of hinges in 15-storey building using IBC2009 (E).

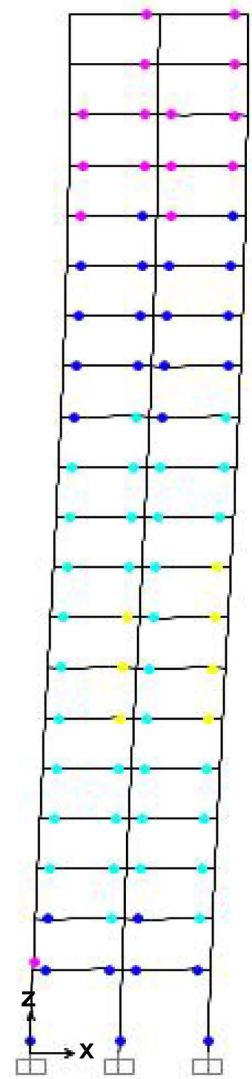

Figure 11. Distribution of hinges in 20-storey building using IBC2009 (CP). 


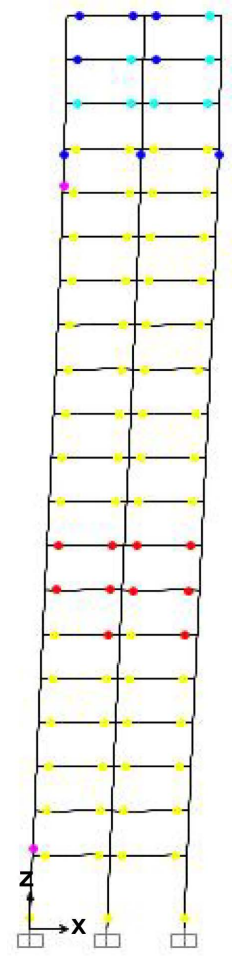

Figure 12. Distribution of hinges in 20-storey building using IBC2009 (E).

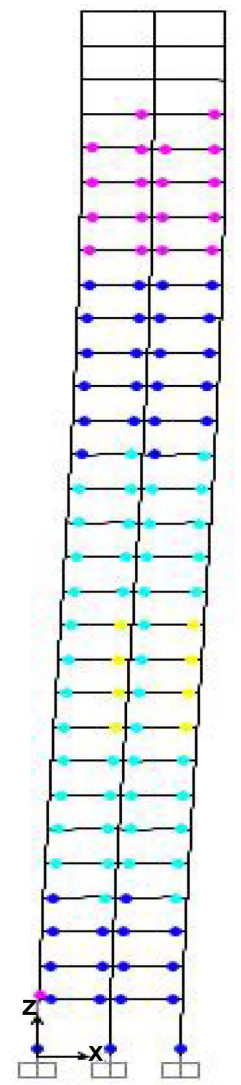

Figure 13. Distribution of hinges in 30-storey building using IBC2009 (CP). 


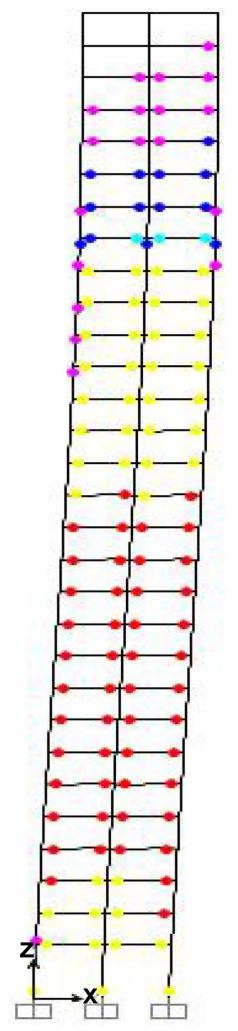

Figure 14. Distribution of hinges in 30-storey building using IBC2009 (E).

From distribution of hinges for 15-storey, it can be noticed that the plastic hinges were located at the fourth, fifth and sixth levels with severe failure. In addition, most of plastic hinges occurred in the beams, which satisfies the weak beam-strong column criteria. Moreover, critical section was located on the columns of the tenth floor, as for these columns the load was released which is an indication for the near failure for the soft storey in building.

As for the 20-storey building the plastic hinges were also located at the intermediate levels with a complete failure in some beams of the seventh and the eighth floors. In addition, a critical section was located on the columns of the seventeenth floor, as for these columns the load was released which is an indication for the near failure for the soft storey in building.

Finally, for the 30-storey building the plastic hinges were located from fourth to fourteenth levels have a complete failure in the beams. Moreover, a critical section was located on the columns of the twenty third floor, as for these columns the load was released which is an indication for the near failure for the soft storey in building.

\subsubsection{Using ESEE Loads}

Similarly, using the ESEE Loading code, Figures 15-22 show the plastic hinges distribution caused as a result for the pushover load affecting the considered RC buildings having heights of 5, 15, 20 and 30 stories with fixed load pattern (Uniform Load Pattern). 


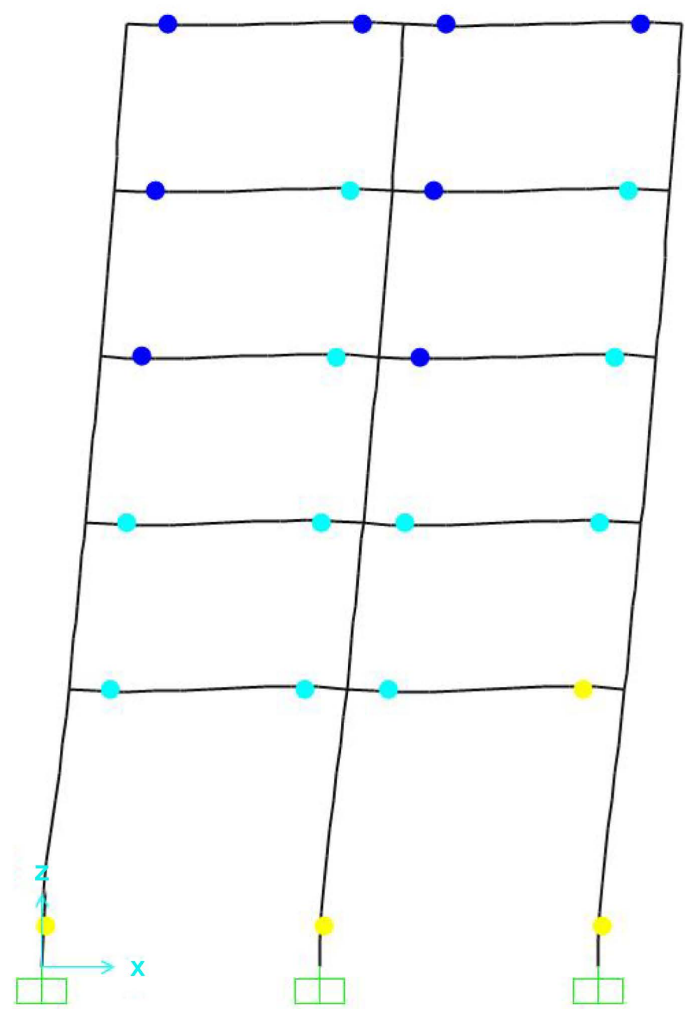

Figure 15. Distribution of hinges in 5-storey building using ESEE (CP).

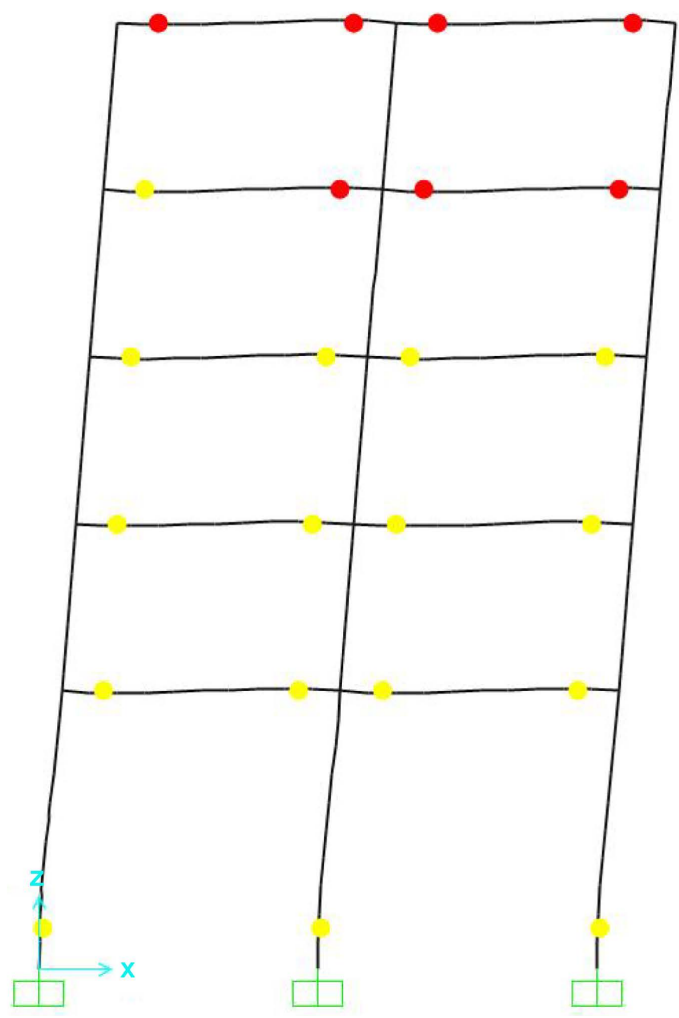

Figure 16. Distribution of hinges in 5-storey building using ESEE (E). 


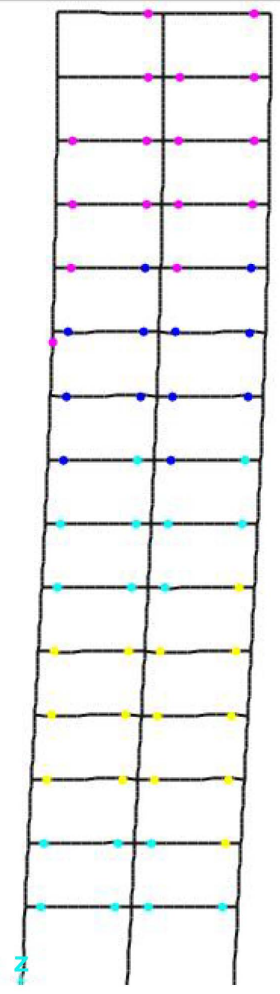

Figure 17. Distribution of hinges in 15-storey building using ESEE (CP).

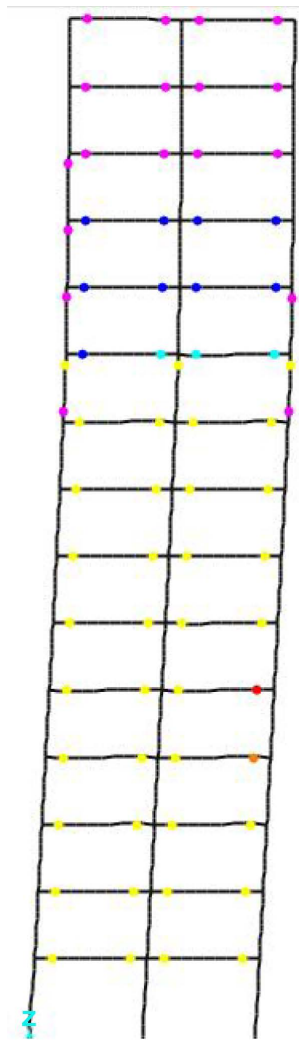

Figure 18. Distribution of hinges in 15-storey building using ESEE (E). 


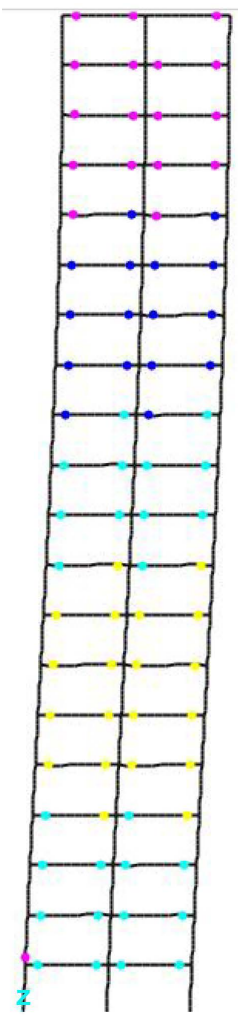

Figure 19. Distribution of hinges in 20-storey building using ESEE (CP).

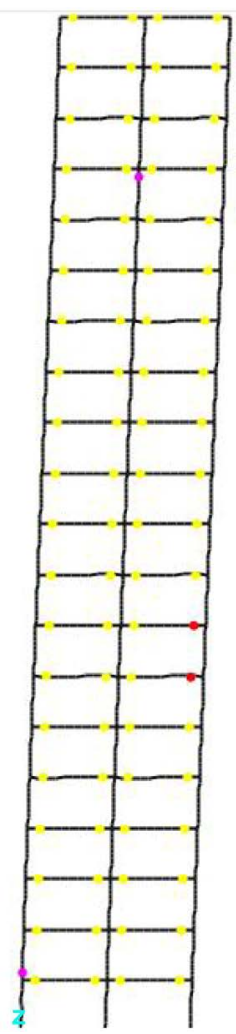

Figure 20. Distribution of hinges in 20-storey building using ESEE (E). 


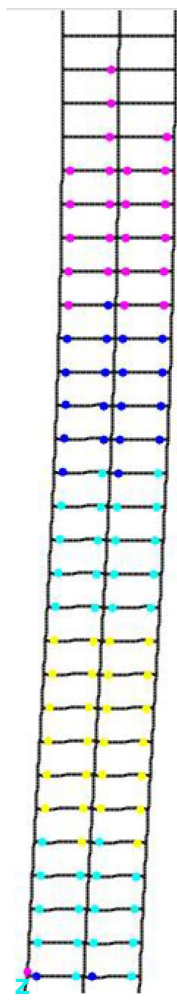

Figure 21. Distribution of hinges in 30-storey building using ESEE (CP).

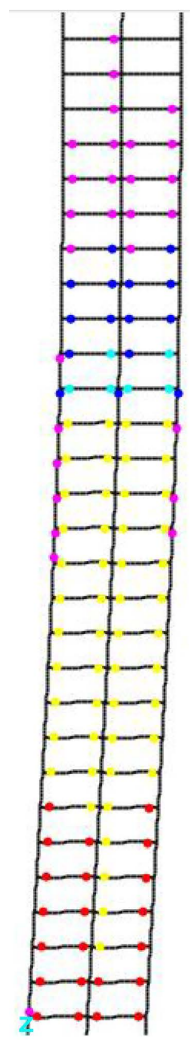

Figure 22. Distribution of hinges in 30-storey building using ESEE (E). 
Similar to the IBC2009, it was found for the ESEE designed 5-storey building that most of plastic hinges occurred in the beams, which satisfies the weak beam-strong column criteria. Moreover, these plastic hinges were located at top levels with severe damage in beams, as the colours indicate the amount of damage.

From distribution of hinges for 15-storiey, it can be noticed that the plastic hinges were located at the fifth floor with severe failure. In addition, a critical section was located on the columns of the eighth floor, as for these columns the load was released which is an indication for the near failure for the soft storey in building. However, this damage was formed after a longer time than for the case of the IBC2009, which indicates that the ESEE building will sustain the earthquake loads higher than the IBC2009 code.

As for the 20-storey building, the plastic hinges were also located at the seventh and eighth levels with some failure in beams.

At last, for the 30-storey building the plastic hinges were located at the low levels with a complete failure in the beams of the first six floors. It was also noticed that there was plastic hinges located on the columns of the fifteenth and nineteenth floors, as for these columns the load was still unreleased which is an indication for the strength of this building code.

\section{Summary and Conclusions}

The IBC2009 and ESEE loads were used to analyze the four RC frames and the cross sections and reinforcement were obtained from the analysis. The plastic hinges properties were assigned to each joint of these frames. A pushover load case was created and assigned to these frames.

This load was located at the center of mass of each floor level. The obtained pushover curves and plastic hinges distribution were the main aspect of comparison between the four buildings using the two codes. The comparison shows that there is variation in the results produced by the two codes, and one of them leads to more vulnerable buildings than the other.

After designing and detailing the reinforced concrete frames, a non-linear static pushover analysis is carried out to evaluate the structural performance of the frames by using both the IBC2009 code and ESEE regulations. By comparing the two codes, the main observations and conclusions drawn are summarized below:

1. Using FEMA-356 [18] Regulations, the distribution of plastic hinges intensity was heavily increased for beams in the IBC2009 compared to the ESEE at different deformation stages. This makes the buildings designed by the ESEE regulations sustain more earthquake loads than those designed by the IBC2009 code at certain loading cases.

2. Using FEMA-356 [18] Regulations, the distribution of plastic hinges intensity was almost similar in both codes for columns. Whereas, there were indications of near soft storey failure in 15, 20 and 30 building models that were designed by IBC2009 code, due to released load in columns. On the other hand, there was indication of 
near soft storey failure in 15-storey building model only, but it took longer time to reach near soft storey failure than case of the IBC2009. Therefore, this shows that the ESEE can perform better in facing earthquake loads.

3. The ESEE Regulations give larger base shear failure results than those obtained by the IBC2009 code. This shows the adequacy of the ESEE Regulations.

4. The obtained beams and external columns cross sections and their reinforcement are the same for both codes, but the ESEE requires bigger cross sections and reinforcement for the internal columns. Thus for the same seismic loads, more plastic hinges will be developed when using the IBC2009 code.

5. It is recommended to use the ESEE code in the seismic design as it has the ability to sustain stronger lateral loads than the IBC2009.

6. The additional cross sections or the reinforcement ratio are not significant, so the additional cost will be low. In fact, considering the safety of the building and lives, the warnings before failure, the building durability on the long run and the higher performance, it is believed that designing according to ESEE Regulations is safer than IBC2009 code.

\section{References}

[1] Sung, Y.C., Lin, T.K., Hsiao, C.C. and Lai, M.C. (2013) Pushover Analysis of Reinforced Concrete Frames Considering Shear Failure at Beam-Column Joints. Earthquake Engineering and Engineering Vibration, 12, 373-383.

http://dx.doi.org/10.1007/s11803-013-0179-8

[2] Hassaballa, A.E., Ismaeil, M.A., Alzead, A.N. and Adam, F.M. (2014) Pushover Analysis of Existing 4 Storey RC Flat Slab Building. International Journal of Sciences: Basic and Applied Research (IJSBAR), 16, 242-257.

http://gssrr.org/index.php?journal=JournalOfBasicAndApplied\&page=article\&op=downloa d\&path\%5B\%5D=2419\&path\%5B\%5D=1789.

[3] CSI. SAP2000 V-14 (2010) Integrated Finite Element Analysis and Design of Structures Basic Analysis Reference Manual. Computers and Structures Inc., Berkeley.

[4] Maske Abhijeet, A., Maske Nikhil, A. and Shiras Preeti, P. (2014) Pushover Analysis of Reinforced Concrete Frame Structures: A Case Study. International Journal of Advanced Technology in Engineering and Science (IJATES), 2, 118-128.

http://ijates.com/images/short_pdf/1413745743_P118-128.pdf

[5] Choudhary, N. and Wadia, M. (2014) Pushover Analysis of R.C. Frame Building with Shear Wall. IOSR Journal of Mechanical and Civil Engineering (IOSR-JMCE), 11, 9-13. http://dx.doi.org/10.9790/1684-11250913 http://www.iosrjournals.org/iosr-jmce/papers/vol11-issue2/Version-5/B011250913.pdf

[6] Aleksieva Gergana (2015) Nonlinear Analysis of a Reinforced Concrete Frame. International Journal of Civil and Structural Engineering Research, 3, 156-163.

[7] OpenSees (2006) Open System for Earthquake Engineering Simulation. Pacific Earthquake Engineering Research Center, University of California, Berkeley.

[8] Kadlag, V.A. and Kenkar, K.S. (2016) Pushover Analysis of RC Frames by Considering Bay Width Variation of Structures. International Journal of Research, 3, 19-22. http://edupediapublications.org/journals/index.php/IJR/article/view/4169/4005

[9] Keerthan, M.S. and Jayashankar Babu, B.S. (2016) Seismic Performance Study of RC 
Frames with Mass Irregularity from Pushover Analysis. International Journal of Engineering Science and Computing, 6.

http://ijesc.org/upload/d1507dd4abde1944a06a3157798a32f2.Seismic\%20Performance\%20Stu dy\%20of\%20RC\%20Frames\%20with\%20Mass\%20Irregularity\%20from\%20Pushover\%20Anal ysis.pdf

[10] IBC2009 (2009) International Building Code. International Code Council.

[11] ESEE (1988) Regulations for Earthquake-Resistant Design of Buildings in Egypt. The Egyptian Society for Earthquake Engineering.

[12] Mouzzoun, M., Moustachi, O., Taleb, A. and Jalal, S. (2013) Seismic Performance Assessment of Reinforced Concrete Buildings Using Pushover Analysis. Journal of Mechanical and Civil Engineering, 5, 44-49. http://dx.doi.org/10.9790/1684-0514449 http://iosrjournals.org/iosr-jmce/papers/vol5-issue1/E0514449.pdf?id=2494

[13] Raut, A.V. and Prasad, R.V.R.K. (2014) Pushover Analysis of G+ 3 Reinforced Concrete Building with Soft Storey. Journal of Mechanical and Civil Engineering, 11, 25-29. http://dx.doi.org/10.9790/1684-11412529

[14] Ashraf Habibullah, S.E. and Stephen Pyle, S.E. (1988) Practical Three Dimensional Nonlinear Static Pushover Analysis. Structure Magazine, 2. http://computersandengineering.de/downloads/technical_papers/CSI/PushoverPaper.pdf

[15] American Society of Civil Engineering (2005) Minimum Loads for Buildings and Other Structures, (ASCE 7-05). Reston.

[16] American Concrete Institute (2008) Building Code Requirements for Structural Concrete (ACI 318-08) and Commentary. Farmington Hills.

[17] Computer and Structures, Inc. (CSI) (2009) SAP2000/NL-PUSH Software Version 15.0. Computer and Structures, Inc., Berkeley.

[18] Federal Emergency Management Agency FEMA 356 (2000) Pre Standard and Commentary for the Seismic Rehabilitation of Buildings.

Submit or recommend next manuscript to SCIRP and we will provide best service for you:

Accepting pre-submission inquiries through Email, Facebook, LinkedIn, Twitter, etc. A wide selection of journals (inclusive of 9 subjects, more than 200 journals)

Providing 24-hour high-quality service

User-friendly online submission system

Fair and swift peer-review system

Efficient typesetting and proofreading procedure

Display of the result of downloads and visits, as well as the number of cited articles Maximum dissemination of your research work

Submit your manuscript at: http://papersubmission.scirp.org/ 